\title{
Protecting Trade Secrets in Canada
}

\author{
Noel Courage and Janice Calzavara \\ Bereskin \& Parr, Toronto, Ontario M5H 3Y2, Canada \\ Correspondence: ncourage@bereskinparr.com
}

Patents in the life sciences industries are a key form of intellectual property (IP), particularly for products such as brand-name drugs and medical devices. However, trade secrets can also be a useful tool for many types of innovations. In appropriate cases, trade secrets can offer long-term protection of IP for a lower financial cost than patenting. This type of protection must be approached with caution as there is little room for error when protecting a trade secret. Strong agreements and scrupulous security can help to protect the secret. Once a trade secret is disclosed to the public, it cannot be restored as the owner's property; however, if the information is kept from the public domain, the owner can have a property right of unlimited duration in the information. In some situations patents and trade secrets may be used cooperatively to protect innovation, particularly for manufacturing processes.

\begin{abstract}
$\mathrm{A}_{\text {trade secret is an intellectual property (IP) }}{ }^{1}$ Aasset based on special types of proprietary confidential information. ${ }^{2}$ Trade secrets are commonly used in innovative industries, and this article focuses on the life sciences industry, such as biotechnology, pharmaceutical, and medical device companies. Trade secrets encompass many areas, such as product secrets (e.g., chemical formulas), technological processes, strategic business information (e.g., customer lists), and specialized compilations of information. ${ }^{3}$ For example, trade secrets may include processes of synthesizing pharmaceuti-
\end{abstract}

${ }^{1}$ R.L. Crain Ltd. v. R.W. Ashton \& Ashton Press Manufacturing Co. (1948), [1949] 2 D.L.R. 481, [1949] O.R. 303, 9 C.P.R. 143 at 149 (S.C.).

${ }^{2} R$ v. Stewart, [1988] 1 S.C.R. 963 at $974-975,65$ O.R. (2d) 637; CPC International Inc. v. Seaforth Creamery Inc., [1996] O.J. No. 2059, 70 C.P.R. (3d) 434 at para. 5 (Ct. J. (Gen. Div.)). cals, fermentation processes for production of biologics, manufacturing processes for medical devices, or diagnostic service laboratory methodologies. In the agricultural biotechnology and food processing industries, there may be trade secrets around the selection, growing, and factory processing of foods.

Trade secret IP rights are under provincial jurisdiction, ${ }^{4}$ which is in contrast to most other types of IP in Canada, such as patents, trademarks, and copyrights, that are created by federal statutes. No Canadian province has a uniform trade secrets statute of the type adopted by most U.S. states. Instead, general principles of trade secret law have been set by the Supreme

\footnotetext{
${ }^{3}$ Institute of Law Research and Reform. 1986. Trade Secrets (Report No. 46), p. 256. University of Alberta, Edmonton, $\mathrm{AB}$, Canada.

${ }^{4}$ MacDonald v. Vapor Canada Ltd., [1997] 2 S.C.R. 134, 22 C.P.R. (2d) 1.
}

Editors: Salim Mamajiwalla and Rochelle Seide

Additional Perspectives on Intellectual Property in Molecular Medicine available at www.perspectivesinmedicine.org

Copyright (C) 2015 Cold Spring Harbor Laboratory Press; all rights reserved; doi: 10.1101/cshperspect.a024489

Cite this article as Cold Spring Harb Perspect Med 2015;5:a024489 
Court of Canada. An example of the Supreme Court's judicial definition of a "trade secret" is a

... plan or process, tool mechanism or compound known only to its owner and those of his employees to whom it is necessary to confide it ... a secret formula or process not patented, but known only to certain individuals using it in compounding some article of trade having a commercial value and does not denote the mere privacy with which an ordinary commercial business is carried on. ... A trade secret may consist of any formula, pattern, device, or compilation of information which is used in one's business, and which gives him an opportunity to obtain an advantage over competitors who do not know or use it. A trade secret is a process or device for continuous use in the operation of the business. The subject matter of a trade secret must be secret. ${ }^{5}$

Both the specific criteria for what qualifies as a trade secret and the scope of protection can vary between the courts of each province. Not all secret information is a trade secret. In some cases, nontechnical information that is proprietary (e.g., price lists) may not qualify as trade secrets. ${ }^{6}$

Trade secrets do not have to encompass only new ideas, but can also cover combinations of known things so long as the conglomerate is novel and unknown. ${ }^{7}$ This means that although each individual step in a process or chemical in a compound is known, the overall process or compound is still a trade secret if the sum of the parts is unknown. An example that has aris-

${ }^{5}$ R.L. Crain Ltd. v. R.W. Ashton \& Ashton Press Manufacturing Co. (1948), [ 1949] 2 D.L.R. 481, [1949] O.R. 303, 9 C.P.R. 143 at 149 (S.C.), cited in Merck Frosst Canada Ltée c. Canada (Ministre de la Santé), 2012 SCC 3, 1 [2012] 1 S.C.R. 23 at paras. 105-107. See also Hughes RT, Clarizio DP, Woodley JH. 2005. Hughes and Woodley on Patents, 2nd ed. vol. 1. (loose-leaf updated 2014, release 39) at $\$ 102$. LexisNexis Canada Inc., Markham, ON, Canada; and Hughes RT, Clarizio DP. 2007. Halsbury's Laws of Canada-Patents, Trade Secrets and Industrial Designs, 1st ed. (Markham, ON, Canada: LexisNexis Canada), "Trade Secrets," p. HPT-180.

${ }^{6}$ Vapor Canada Ltd. v. MacDonald (1972), 6 C.P.R. (2d) 240 (F.C.T.D.), affirmed (1972), 8 C.P.R. (2d) 15, 33 D.L.R. (3d) 434 (Fed. C.A.), reversed on other grounds [1977] 2 S.C.R. 134, 22 C.P.R. (2d) 1; Schauenburg Industries Ltd. v. Borowski (1979), 25 O.R. (2d) 737, 50 C.P.R. (2d) 69 (H.C.J.).

${ }^{7}$ Di Giacomo v. Di Giacomo Canada Inc., [1989] O.J. No. 1666, 28 C.P.R. (3d) 77 at 104 (H.C.J.). en in a Canadian court case is Hellmann's ${ }^{\circledR}$ Mayonnaise: Although the ingredients used in the preparation of its signature product may be known compounds and listed on the label, the exact proportions and chemical identity of certain ingredients can be trade secrets. ${ }^{8}$ Therefore, even though there is much public domain knowledge of generally similar mayonnaise recipes, that alone is not definitive of whether that information as it is being used is a trade secret. ${ }^{9}$

\section{TRADE SECRETS VERSUS TRADE KNOWLEDGE}

Trade secrets are not the same as trade knowledge, which is the general skill and knowledge one gains during one's employment. An agreement that restricts an employee's ability to practice a trade is usually void unless it can be shown that the restriction meets the difficult test of being both reasonable and in the public interest. ${ }^{10}$

A trade secret may be more likely to be viewed as trade knowledge if it cannot be shown that a reasonable person would have understood that the information disclosed was confidential. ${ }^{11}$ An employer's ongoing, explicit delineations given during employment of what are trade secrets can be helpful evidence in court of a confidential, proprietary interest. It is also beneficial to draft a confidentiality clause into the employment contract of any employees who may have access to the trade secret. In the absence of such a clause and practical precautions to indicate and preserve confidentiality, certain information conveyed to the employee may be

\footnotetext{
${ }^{8}$ CPC International Inc. v. Seaforth Creamery Inc., [1996] O.J. No. 3393, 69 C.P.R. (3d) 297 at 305, 310-311 (Ct. J. (Gen. Div.)).

${ }^{9}$ CPC International Inc. v. Seaforth Creamery Inc.

${ }^{10}$ Drake International Ltd. v. Miller (1975), 9 O.R. (2d) 652, 21 C.P.R. (2d) 129 at 133 (S.C.), citing Herbert Morris, Ltd. v. Saxelby, [1916] 1 A.C. 688 at 709 (H.L.); J.G. Collins Insurance Agencies Ltd. v. Elsley, [1978] 2 S.C.R. 916 at 923, 36 C.P.R. (2d) 65.

${ }^{11} \mathrm{~A}$ good summary on the difference between trade secrets and trade knowledge is available in paragraphs $280-284$ of the trial decision of Apotex Fermentation Inc. v. Novopharm Ltd. (1995), 128 D.L.R. (4th) 277, 63 C.P.R. (3d) 77 (Man. Q.B.), reversed on other grounds (1998), 162 D.L.R. (4th) 111, 80 C.P.R. (3d) 449 (Man. C.A.).
} 
more likely to appear to be trade knowledge that the employee can later use to compete against a former employer.

\section{TRADE SECRET DURATION/LOSS OF RIGHTS IN A TRADE SECRET}

The potential long life of a trade secret is one of the key attributes of its protection. If a trade secret becomes public knowledge, that disclosure removes the trade secret protection. ${ }^{12}$ If the secret is discovered by examination of the product, experimentation, or any other honest method, the discoverer has a right to use that information. ${ }^{13}$ However, there may still be liability where a company misuses a collaborator's trade secret even though the trade secret could have been independently discovered through public domain information. ${ }^{14}$

\section{CREATING AND MANAGING TRADE SECRET RIGHTS}

When trade secrets are shared with employees, contractors, research collaborators, or business partners, the secret must be controlled and managed carefully. Steps should be taken to share the secret under conditions in which the property rights in the secret can be enforced through legal action, if necessary. The onus is on the owner to prove the existence of the trade secret in any litigation. ${ }^{15}$

A lawsuit for breach of confidence can be brought when a trade secret owner can show that:

1. the information conveyed was confidential;

2. the information was communicated in confidence;

${ }^{12}$ R.L. Crain Ltd. v. R.W. Ashton \& Ashton Press Manufacturing Co. (1949), [1950] O.R. 62, 11 C.P.R. 53 at 62 (C.A.).

${ }^{13}$ R.L. Crain Ltd. v. R.W. Ashton \& Ashton Press Manufacturing Co. (1948), [1949] O.R. 303, 9 C.P.R. 143 at 149-150 (S.C.).

${ }^{14}$ Use of public domain information is discussed in more depth in the later section regarding springboarding.

${ }^{15}$ R.L. Crain Ltd. v. R.W. Ashton \& Ashton Press Manufacturing Co. (1949), [1950] O.R. 62, 11 C.P.R. 53 at 64 (C.A.).
3. the information was misused by the party to whom it was communicated. ${ }^{16}$

The first stage of the trade secret test (the information must be confidential) considers a number of factors, including:

- how much the information is generally known or unknown to others (both in and outside the industry);

- how much the information is capable of being acquired by outside individuals;

- the measures used to keep the information confidential;

- to what level the information is unique; ${ }^{17}$

- how many employees know the secret;

- the extent that the secret is known outside the business;

- the value of the secret to the business;

- the cost and difficulty researching the subject matter that is the trade secret. ${ }^{18}$

This is not an exhaustive list, and information does not have to satisfy all criteria to be considered a trade secret.

For the second stage of the test, the information must also have been obtained in a confidential manner, either explicitly or implicitly, to be protected. ${ }^{19}$ Simply stating that informa-

${ }^{16}$ International Corona Resources Ltd. v. Lac Minerals Ltd., [1989] 2 S.C.R. 574 at 635-636, 61 D.L.R. (4th) 14, citing Coco v. A.N. Clark (Engineers) Ltd., [1969] R.P.C. 41 at 47 (Ch.). This "proof" does not have to be direct proof beyond a shadow of a doubt, but instead can be circumstantial in nature, simply making the existence of a trade secret more likely than not: Omega Digital Data Inc. v. Airos Technology Inc., [1996] O.J. No. 5382, 32 O.R. (3d) 21 at 28 (Ct. J. (Gen. Div.)), quoting Matrox Electronic Systems Ltd. v. Godrow, [1993] R.J.Q. 2249 (S.C.).

${ }^{17}$ Thorburn JA, Fairbairn KG. 1998. Law of Confidential Business Information (loose-leaf updated 2014, release 18), chapter 3 at para. 2100. Thomson Reuters Canada Limited, Toronto.

${ }^{18}$ Alberta Productions Corp. v. Canada Lands Co. CLC Ltd. (2001) ABQB 747 at paras. 106-107, 292 A.R. 8, affirmed (2004), ABCA 11, 346 A.R. 177.

${ }^{19}$ Hughes RT, Clarizio DP, Woodley JH. 2005. Hughes and Woodley on Patents, 2nd ed. vol. 1. (loose-leaf updated 2014, release 39) at \$102. LexisNexis Canada Inc., Markham, ON, Canada. 
tion is confidential may not be sufficient to establish protection if there is reason to think that, despite the confidentiality warnings, the information was not a secret. ${ }^{20}$ An example of this was a report given to a newspaper: Although the person disclosing the report said the contents were confidential, no confidentiality was actually found because when a resource is given to a newspaper, there is an expectation that the resource will be published. ${ }^{21}$ Therefore, a report that cost $\$ 33,000$ to purchase was deemed not confidential after it was given to a newspaper, even though the transfer of the document was riddled with "confidential" warnings. Information presented to fellow researchers, potential investors, and commercial partners at an open life sciences conference is also unlikely to be considered confidential, even if slides and handouts are marked as such.

When determining whether information was passed in a confidential manner, the "reasonable person" test is applied: Would a person acting reasonably have expected the information to be confidential? $?^{22}$ Therefore, even if a party is not warned and may not have known that the information was confidential, if a reasonable person in their position would have thought that the information was confidential, that is sufficient to make that information confidential. Thus, when discussing trade secrets, it is best to make it unambiguously clear, both with words and with the circumstances surrounding the transfer of the information, that the trade secret is confidential and may only be used for permitted purposes.

\section{EMPLOYEES AND TRADE SECRETS}

It is common in life sciences that employees leave their positions and work for competitors. An obligation to protect trade secrets learned

\footnotetext{
${ }^{20}$ B.W. International Inc. v. Thomson Canada Ltd. (1996), 137 D.L.R. (4th) 398, 68 C.P.R. (3d) 289 (Ont. Ct. J. (Gen. Div.)).

${ }^{21}$ B.W. International Inc. v. Thomson Canada Ltd.

${ }^{22}$ International Corona Resources Ltd. v. Lac Minerals Ltd., [1989] 2 S.C.R. 574, 61 D.L.R. (4th) 14, citing Coco v. A.N. Clark (Engineers) Ltd., [1969] R.P.C. 41 at 48 (Ch.).
}

during the course of employment can arise through an explicit written or oral agreement or other circumstances indicating an implied obligation of confidentiality. Regardless of any agreements that may be in place, it is generally best to share trade secrets with employees on a need-to-know basis, and only disclose them when necessary.

\section{No Agreement}

In the absence of an agreement, there is an implied obligation by the employee not to use special information for his or her own benefit and contrary to the interests of the employer. ${ }^{23}$ This obligation stems from the duty of good faith the employee has toward the employer. ${ }^{24}$ Several factors are considered when determining if there is an implied term of nondisclosure, including the nature of the employment. ${ }^{25} \mathrm{Al}-$ though all employees owe a duty of good faith to their employer, the nature of the employment is relevant: the less senior the employee, the lower the expectation that information given to that employee is sensitive. ${ }^{26}$ In a life sciences company context, a principal investigator will have a higher obligation than a lab technician. An employment agreement containing confidentiality clauses is a prudent precaution for any level of employee contacting confidential information.

An additional, higher obligation can stem from the fiduciary duty that the employee may owe the company, but that is separate from the employee's basic duty of good faith required when holding trade secrets. ${ }^{27}$ Fiduciary duty can impose additional obligations on certain

\footnotetext{
${ }^{23}$ Bee Chemical Co. v. Plastic Paint \& Finish Specialties Ltd., [1978] O.J. No. 522, 41 C.P.R. (2d) 175 at 180 (H.C.J.), affirmed [1979] O.J. No. 1062, 47 C.P.R. (2d) 133 (C.A.), leave to appeal to S.C.C. refused, 47 C.P.R. (2d) 133n, 30 N.R. 356n.

${ }^{24}$ State Vacuum Stores of Canada Ltd. v. Phillips, [1954] 3 D.L.R. 621,12 W.W.R. (N.S.) 489 at para. 4 (B.C.C.A.).

${ }^{25}$ Faccenda Chicken Ltd. v. Fowler, [1987] Ch. 117, [1986] 1 All E.R. 625.

${ }^{26}$ Faccenda Chicken Ltd. v. Fowler.

${ }^{27} 60630$ Manitoba Ltd. v. McCarroll (1995), 102 Man. R. (2d) 277, 61 C.P.R. (3d) 572 at 575 (C.A.).
} 
employees, such as high-level executives, not to act against a company's interest. ${ }^{28}$ For example, a chief scientific officer is likely to encounter a wide variety of highly confidential scientific and business information and be under a fiduciary duty to the company.

\section{Express Agreement}

The best employer practice is to set out clearly written expectations and boundaries. Using a written agreement shows an attempt to curtail the spread of information, which can be helpful in proving that there was a trade secret in the first place.

Contract terms can be drafted broadly to strengthen the ability to protect and enforce the trade secret rights, compared to the uncertainties of a situation where there is no agreement in place. A confidentiality agreement will clearly outline to an employee the expectations of the employer and the repercussions for not abiding by these expectations. Departing employees can also be asked to read and sign exit agreements as a reminder of the obligations to which they have agreed. Written agreements should set out the obligations for the employee for both during the course of their employment and after their employment ends. These types of agreements signify to the court that the knowledge being transferred is sensitive and that care was taken to try to protect the secrets.

\section{Incoming Employees and Collaborations}

Incoming employees and research collaborators should agree not to use trade secrets obtained from their previous work for competitors. If an employer knows or is wilfully blind regarding whether an incoming employee has trade secrets from a previous employer, the employer can be held liable for a breach of confidence if those

${ }^{28}$ Canadian Aero Services Ltd. v. O’Malley (1973), [1974] S.C.R. 592 at 606-610, 11 C.P.R. (2d) 206; Wormald Canada Inc. v. Classic Fire Protection Inc. (1988), 23 C.P.R. (3d) 259 (Ont. H.C.J.) secrets are used. ${ }^{29}$ Therefore, actual knowledge that the employee has, and misused, trade secrets is not necessary for liability.

When courts try to determine whether trade secrets have been wrongfully used by an incoming employee and the new employer, evidence of "springboarding" is often an indicator that the new employer has benefited from more than just the employee's general skills and knowledge. Springboarding is a characteristic of misappropriation of confidential information that refers to the advantage a competitor gains by using the trade secret or confidential information in lieu of having to experiment and discover the information for itself. ${ }^{30}$ For example, if finding fermentation conditions to produce $x$ $\mathrm{mg} / \mathrm{L}$ of drug typically takes 2 years of trial and error, and a newly hired employee uses trade secrets from a previous employer to achieve this solution in less time, that is springboarding. Companies should use reasonable diligence to assess significant research and development shortcuts suggested by new employees to ensure they can be used without risk.

\section{TRADE SECRETS VERSUS PATENTS}

The decision of whether to protect IP primarily by trade secret or patent is highly dependent on the type of technology. Both patents and trade secrets are assets that may be readily commercialized by sale or license. Ideas or technology can only be protected as a trade secret for the duration that they remain secret. Patents are published and typically disclose a sufficient amount for someone skilled in the art to make and use the invention, so that the technology

\footnotetext{
${ }^{29}$ Apotex Fermentation Inc. v. Novopharm Ltd. (1995), 128 D.L.R. (4th) 277, 63 C.P.R. (3d) 77 (Man. Q.B.), reversed on other grounds (1998), 162 D.L.R. (4th) 111, 80 C.P.R. (3d) 449 at paras. 117-118, 150 (Man. C.A.). A departed employee misappropriating trade secrets for his new company recently resulted in the Ontario Superior Court awarding more than $\$ 6,500,000$ to the trade secret owner, Imax Corp. (See Imax Corp. v. Trotum Systems Inc., 2014 ONSC 3863).

${ }^{30}$ Cranleigh Precision Engineering, Ltd. v. Bryant, [1964] 3 All E.R. 289 (Q.B.); International Corona Resources Ltd. v. Lac Minerals Ltd., [1989] 2 S.C.R. 574 at 637-638, 26 C.P.R. (3d) 97.
} 
can no longer be a secret. ${ }^{31}$ In this regard, patents and trade secrets are incompatible. Pharmaceuticals are generally protected by patents, not trade secrets, because the drug structure must be disclosed to the public for regulatory purposes. Even if, hypothetically, the structure was not disclosed, in many cases the structure could be reverse engineered, eliminating any possibility of protection as a trade secret. This can be a challenge of keeping any chemical composition as a trade secret. Although a pharmaceutical structure itself may not be an ideal candidate, the process used to make the formulation may be capable of being kept as a trade secret. ${ }^{32}$ The proportions of the finished pharmaceutical formulation may also be a trade secret if the formulation is complex and includes multiple inactive ingredients such as stabilizers, binding agents, and tableting aids.

Trade secrets can offer longer protection than a patent. Patents provide a maximum 20 year exclusive monopoly to make, use, and sell an invention, after which the invention becomes public domain. ${ }^{33}$ This monopoly is enforceable even against others with no knowledge of the patent. A trade secret does not provide an exclusive monopoly to make, use, and sell the secret innovation-it provides rights enforceable against misappropriation. However, a trade secret can potentially remain confidential indefinitely. Consider Coca-Cola ${ }^{\circledR}$ : Had the company opted for a patent on the novel soft-drink composition, the patent would have since expired and the information contained within would be free for anyone to use. As it stands, the Coca-Cola recipe is still a valuable trade secret asset, protected globally, and only the Coca-

\footnotetext{
${ }^{31}$ R.L. Crain Ltd. v. R.W. Ashton \& Ashton Press Manufacturing Co. (1949), [1950] O.R. 62, 11 C.P.R. 53 (C.A.); RobinNodwell Manufacturing Ltd. v. Foremost Developments Ltd. (1966), 38 Fox Pat. C. 43, 52 C.P.R. 244 at 249-250 (Alta. S.C.), citing O. Mustad \& Son v. Allcock \& Co., Ltd., [1963] 3 All E.R. 416 (H.L.)

${ }^{32}$ Belform Insulation Ltd. v. Toleks Insulation Ltd. (1998), 85 C.P.R. (3d) 160 at paras. 11-15 (Ont. Ct. J. (Gen. Div.)).

${ }^{33}$ Patent Act, R.S.C. 1985 , c. P-4, s. 44. Patent term extension is not currently available in Canada, but is available in some other countries.
}

Cola Company produces that exact product recipe. $^{34}$

When deciding between patents and trade secrets, there are many issues to consider. One important aspect is how easily the product can be reverse engineered. For products that are easily analyzed and deconstructed, trade secrets are not likely to have enduring value because there will be little protection afforded to such an easily elucidated technology once it has been put up for sale. ${ }^{35}$ Additionally, if no residual telltale compounds remain in the final product, a process to make a known molecule may be protected as a trade secret. However, if by-products or impurities can reveal the process used in the manufacture of the final product, trade secrets are likely not a prudent method of protection.

Patents may also be a better strategy than trade secrets in some circumstances where competitors are likely to independently develop similar technology. If an invention is kept as a trade secret by the first inventor, a subsequent inventor independently making a similar invention may still get a patent for the invention. This situation can create a freedom-to-operate issue for the trade secret owner because most countries have very limited rights, or no rights, to keep using an invention based on prior, secret use.

Financially, trade secrets usually cost less to protect than patents. Patents must be filed in each country of interest or else the rights become public domain in that country. Canadian and U.S. patents can, in some cases, cost tens of thousands of dollars in government and attorney fees to draft, register, and maintain. Costs are much higher if protecting patent rights internationally. A trade secret offers worldwide protection and only costs as much as it takes to keep it a secret.

Another major difference is that with a trade secret, the cost ends at protecting that secret-

\footnotetext{
${ }^{34}$ It should be noted that the value of the Coca-Cola ${ }^{\circledR}$ product and company also relies heavily on trademark IP in addition to the trade secret

${ }^{35}$ Stenada Marketing Ltd. v. Nazareno, [1990] B.C.W.L.D. 2493, 33 C.P.R. (3d) 367 at 375 (S.C.), citing Coco v. A.N Clark (Engineers) Ltd., [1969] R.P.C. 41 at 47 (Ch.).
} 
once the secret is leaked, no further amount of money will make that knowledge a trade secret again. Patent owners still have their patent rights intact and enforceable regardless of what public or private misuse has been made of the protected technology.

When considering enforcement, the patent owner may begin in a more certain position with respect to the rights that he or she possesses. A Canadian patent is examined by the Canadian Intellectual Property Office to set the scope of rights. The patent rights are presumed prima facie valid in litigation, and an opposing party has the burden to provide some evidence to put the validity of the patent in issue. ${ }^{36}$ However, the onus rests on the owner of a trade secret to prove that he or she has a trade secret. ${ }^{37}$

Because not every technology is patentable, the subject matter of the innovation is another issue to consider. Specifically, certain business methods, computer software-implemented processes, and abstract scientific formulas are not patentable subject matter in Canada. ${ }^{38}$ Higher life forms, such as transgenic mice and plants, are also not patentable in Canada. $^{39}$ If satisfactory patent protection is not available, trade secrets in relation to processes of use or manufacture may be a reasonable approach. Additionally, products that will be developed and improved upon as time progresses may end up benefiting from patent rights in the original invention, and trade secret protection in the improvements made after the patent is filed (such as scale-up manufacturing techniques). Patents are not typically filed again on every small, incremental improvement, so there remains a role for trade secrets, even when patents are used.

Trade secrets and patents can also be used in conjunction. For example, a technology may be

\footnotetext{
${ }^{36}$ Patent Act, R.S.C. 1985 , c. P-4, s. $43(2)$ as amended S.C. 1993, C. 15 , s. 42.

${ }^{37}$ CPC International Inc. v. Seaforth Creamery Inc., [1996] O.J. No. 2059, 70 C.P.R. (3d) 434 at para. 12 (Ct. J. (Gen. Div.)).

${ }^{38}$ Patent Act, R.S.C. 1985 , c. P-4, s. 27(8).

${ }^{39}$ Harvard College v. Canada (Commissioner of Patents), 2002 SCC 76, [2002] 4 S.C.R. 45.
}

kept a trade secret initially and then later be patented ( provided that no competitor has filed an earlier patent application for the same invention in the interim). Some countries also have a grace period between public disclosure and filing a patent. For example, patents may be filed in Canada or the United States by a 1-year deadline after the date of first disclosure by the applicant. ${ }^{40}$ Therefore, if a trade secret is accidently disclosed, there may still be an option to protect the secret by patenting.

\section{ENFORCING TRADE SECRET RIGHTS}

The mere copying and taking of trade secret information per se without permission may not be a criminal offense in Canada because the Criminal Code $e^{41}$ does not define trade secrets as "property." 42 The theft of trade secrets is a civil infraction, but can lead to criminal charges if the secrets are obtained by trespassing or by taking a physical object owned by the company that contains the trade secrets, such as paper-based documents or a hard drive.

\section{Damages}

Monetary compensation may be granted against a party responsible for the loss of a trade secret. A trade secret owner can initiate a lawsuit if an imminent breach of confidence by disclosure or other misuse of confidential information is likely to cause them loss. ${ }^{43}$ If loss does occur as a result of the disclosure, then the remedies available for a breach of confidence regarding disclosing a trade secret can include either damages (monetary compensation for losses) or an accounting of profits (a monetary award based on the extra profits earned by a competitor from misuse of the information). The amount of money awarded for damages will depend on the type of secret disclosed and the general circumstances surrounding the dis-

\footnotetext{
${ }^{40}$ Patent Act, R.S.C. 1985 , c. P-4, s. 28.2.

${ }^{41}$ R.S.C. 1985 , c. C-46.

${ }^{42} R$ v. Stewart, [1988] 1 S.C.R. 963, 50 D.L.R. (4th) 1.

${ }^{43}$ International Corona Resources Ltd. v. Lac Minerals Ltd., [1989] 2 S.C.R. 574 at 657, 61 D.L.R. (4th) 14.
} 
closure. A person generally has to elect between damages and an accounting of profits, but can pick the one most favorable to them. ${ }^{44}$

From a practical perspective, the damage suffered from loss of a trade secret, if any, should be sufficient to justify the cost of a lawsuit. If the secrets are of the type that can be purchased, the fair market value could be used as the basis for the monetary damages awarded-this is seldom the case though, as most trade secrets are not typically "for sale." ${ }^{45}$ Overall, the monetary damages will typically reflect the "but for" price of the secret: What would have happened but for the person having misused the trade secret. ${ }^{46}$ If the secret was ordinary or "not very special," the damages awarded will be much lower than if it was the type of secret for which no amount of research would likely ever have afforded the answer. The considerations in arriving at a damages award are complex, and expert scientific and valuation evidence may be necessary. For example, in a springboarding situation, the court considers the difference between having been given the trade secret and deducing the secret personally. The damages awarded will in part reflect the difficulty in ascertaining the secret in question.

\section{Injunction}

The trade secret owner may also request an injunction to prevent initial disclosure or the further misuse of the information. ${ }^{47}$ An injunction is a court order requiring a party to refrain from doing a specific activity for a period of time (either permanently or temporarily). ${ }^{48}$ In Canada, it is difficult to get an injunction in an IP case because courts require proof that, in the absence of the injunction, irreparable harm

\footnotetext{
${ }^{44}$ ICAM Technologies Corp. v. EBCO Industries Ltd., [1993] B.C.W.L.D. 3010, 11 B.L.R. (2d) 205 at para. 19 (C.A.).

${ }^{45}$ Cadbury Schweppes Inc. v. FBI Foods Ltd., [1999] 1 S.C.R. 142 at 184-185, 167 D.L.R. (4th) 577.

${ }^{46}$ International Corona Resources Ltd. v. Lac Minerals Ltd., [1989] 2 S.C.R. 574 at 637-638, 668-670, 61 D.L.R. (4th) 14.

${ }^{47}$ Cadbury Schweppes Inc. v. FBI Foods Ltd.

${ }^{48} 1711811$ Ontario Ltd. v. Buckley Insurance Brokers Ltd., 2014 ONCA 125 at paras. 49-52, 371 D.L.R. (4th) 643.
}

will occur for which money is not sufficient compensation. $^{49}$ If an injunction is sought, the party requesting the injunction must show that it is more likely than not that the injunction only goes as far as necessary to protect the trade secret owner's interests. ${ }^{50}$ Therefore, the more evidence there is regarding the value of the secret and the steps taken to ensure the secret's protection, the more basis there is to justify an injunction. If the information has already been made publicly available, even if available as a result of wrongdoing, the court is less likely to grant an injunction. ${ }^{51}$

\section{CONCLUSION}

Patents in the life sciences industries have been a key form of IP, particularly for products such as brand-name drugs and medical devices. Trade secrets can also be a useful tool for many types of innovations. In appropriate cases trade secrets can offer long-term protection of IP for a lower financial cost than patenting. This type of protection must be approached with caution, as there is little room for error when protecting a trade secret. Strong agreements and scrupulous security can help to protect the secret. Once a trade secret is disclosed to the public, it cannot be restored as the owner's property; however, if the information is kept from the public domain, the owner can have a property right of unlimited duration in the information. In some situations, patents and trade secrets may be used cooperatively to protect innovation, particularly for manufacturing processes.

\footnotetext{
${ }^{49}$ Manitoba (AG) v. Metropolitan Stores Ltd., [1987] 1 S.C.R. 110 at $128-129,38$ D.L.R. (4th) 321, cited in RJR-MacDonald Inc. v. Canada (AG), [1994] 1 S.C.R. 311, 111 D.L.R. (4th) 385.

${ }^{50}$ R.L. Crain Ltd. v. R.W. Ashton \& Ashton Press Manufacturing Co. (1949), [1950] O.R. 62, 11 C.P.R. 53 at 58 (C.A.).

${ }^{51}$ Booty Camp Fitness Inc. v. Jackson (2009), 179 A.C.W.S. (3d) 681, 61 B.L.R. (4th) 79 at paras. 35-36 (Ont. Sup. Ct. J.), additional reasons (2009), 183 A.C.W.S. (3d) 375, leave to appeal to Ont. Div. Ct. refused (2010), 186 A.C.W.S. (3d) 49.
} 


\section{$\&_{\mathrm{CSH}}^{\infty} \&$ Cold Spring Harbor

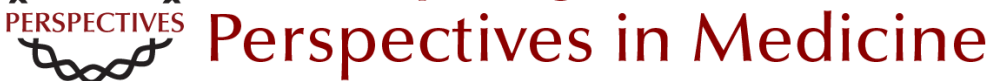

\section{Protecting Trade Secrets in Canada}

Noel Courage and Janice Calzavara

Cold Spring Harb Perspect Med 2015; doi: 10.1101/cshperspect.a024489 originally published online May 18, 2015

\section{Subject Collection Intellectual Property in Molecular Medicine}

Patentability of Stem Cells in the United States Sarah E. Fendrick and Donald L. Zuhn, Jr.

Inventorship and Authorship Antoinette F. Konski and Linda X. Wu

The Patentability of Stem Cells in Australia Jenny Petering and Prue Cowin

Impact of America Invents Act on Biotech Intellectual Property

Amanda Murphy, Michael Stramiello, Jonathan Stroud, et al.

Introduction to Intellectual Property: A U.S.

Perspective

Amanda Murphy, Michael Stramiello, Stacy Lewis, et al.

The Role of Regulatory Agencies and Intellectual Property: Part I

Kevin E. Noonan

Canada's Patented Medicines (Notice of Compliance) Proceedings and Intellectual

Property

Henry Bian and Conor McCourt

Patentability of Genes: A European Union

Perspective

Paul Cole
The Impact of Myriad on the Future Development and Commercialization of DNA-Based Therapies and Diagnostics

Michele Wales and Eddie Cartier

Protecting Traditional Knowledge Related to

Biological Resources: Is Scientific Research

Going to Become More Bureaucratized?

Prashant Reddy and Malathi Lakshmikumaran

Protecting Trade Secrets in Canada

Noel Courage and Janice Calzavara

Inherent Anticipation in the Pharmaceutical and

Biotechnology Industries

Michael Goldman, Georgia Evans and Andrew Zappia

The Role of Regulatory Agencies and Intellectual

Property: Part II

Kevin E. Noonan

Baseball Bats and Chocolate Chip Cookies: The Judicial Treatment of DNA in the Myriad Genetics Litigation lan Binnie and Vanessa Park-Thompson

The Impact of Myriad and Mayo: Will

Advancements in the Biological Sciences $\mathrm{Be}$

Spurred or Disincentivized? (Or Was Biotech

Patenting Not Complicated Enough?) Jennifer Gordon

Trade Secrets in Life Science and Pharmaceutical Companies

Tara Nealey, Ronald M. Daignault and Yu Cai

For additional articles in this collection, see http://perspectivesinmedicine.cshlp.org/cgi/collection/ 